\title{
Apprehension of illegal pesticides, agricultural productivity and food poisoning on the Brazilian state of Mato Grosso do Sul
}

\author{
Apprehension of illegal pesticides, agricultural productivity and food poisoning \\ on the Brazilian state of Mato Grosso do Sul
}

Graziela Dias Ferreira Sant’Ana; Sabrina Helena C. Araújo ${ }^{2 *}$; Jardel L. Pereira ${ }^{3}$; Eugenio E. Oliveira ${ }^{4}$

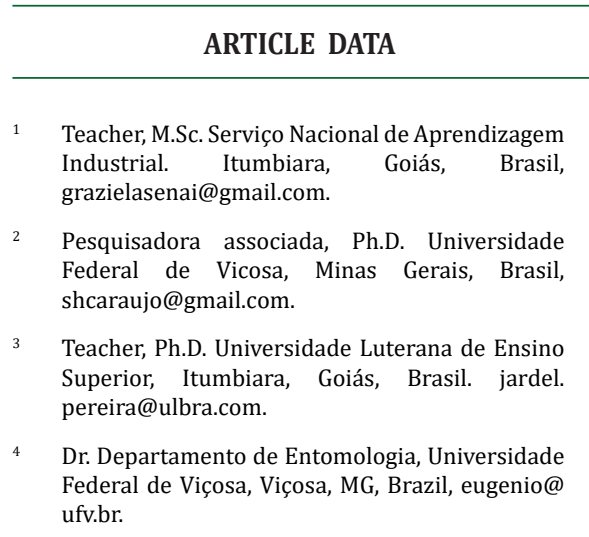

Cite: Sant'Ana, G., Araújo, S., Pereira, J., \& Oliveira, E. (2019). Apprehension of illegal pesticides, agricultural productivity and food poisoning on the Brazilian state of Mato Grosso do Sul. Revista de Ciencias Agrícolas. 36(E): 52-62. doi: https://doi. org/10.22267/rcia.1936E.106

Received: June 222019.

Accepted: October 162019.

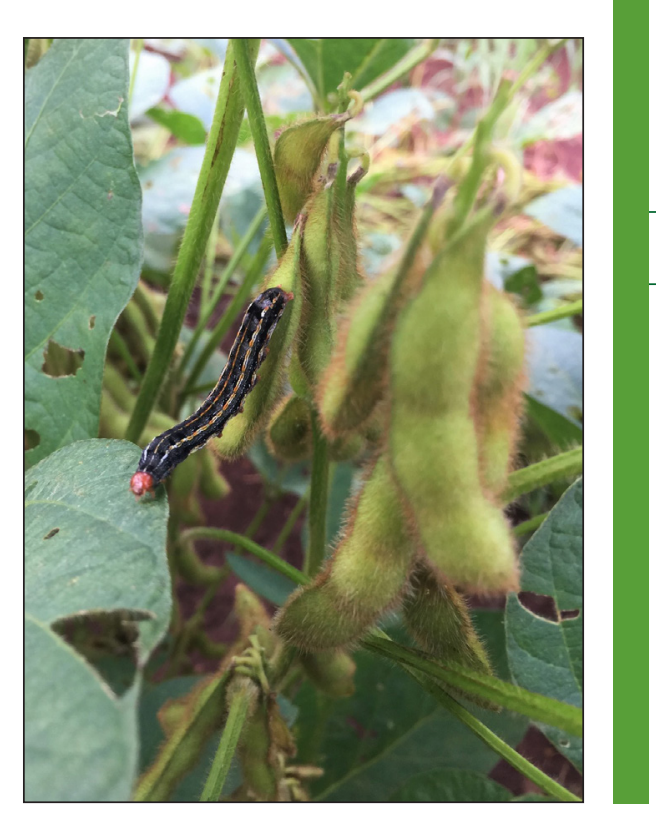

ABSTRACT

The application of agrochemicals plays a key role in the world's food and agricultural products supply. Brazil, as one of the most relevant agricultural global players is highly dependent on the application of such products, which surely attracted not only companies that licitly commercialized the pesticides but also the so termed pesticide smugglers. Here, we conducted a retrospective survey (i.e., from 2010 to 2017) regarding the apprehension of illegal products, agricultural productivity and food poisoning in the state of Mato Grosso do Sul (MS). The statistical data were obtained by official agencies Such as TechnicalScientific Sector of the Federal Police Department of the MS State, The System of Control of Seized Goods, The National Toxic-Pharmacological Information System and The Brazilian Institute of Geography and Statistics, and by the nonofficial National Union of the Product Industry for Plant Protection agency. The results indicated that in 2011 the MS state had the largest number of seizures of illegal pesticides compared to other years. In addition, from 2010 to 2013 , the state was among the regions with the highest number of seizures. In the same period, the agricultural productivity of the cotton, sugarcane, corn and soybean crops was lower compared to the other years. Regarding the food poisoning, the percentage of human intoxication by agrochemicals for agricultural use was low compared to all cases of intoxication by various toxic agents. It was concluded that the state MS presented a large amount of seizure of illegal pesticides.

Key words: Agrochemicals, food intoxications, pesticide smugglers, pesticide toxicology, Neotropical agriculture.

\section{RESUMEN}

La aplicación de agroquímicos desempeña un papel clave en el suministro mundial de alimentos y productos agrícolas. Brasil, como uno de los actores globales agrícolas más relevantes, depende en gran medida de la aplicación de dichos productos, lo que seguramente atrajo no solo a las empresas que comercializaban lícitamente los pesticidas, sino también a los llamados contrabandistas de pesticidas. Aquí, realizamos una encuesta retrospectiva (es decir, de 2010 a 2017) sobre la captura de productos ilegales, la productividad agrícola y la intoxicación alimentaria en el estado de Mato Grosso do Sul (MS). Los datos estadísticos fueron obtenidos por agencias oficiales como el Sector Técnico-Científico del Departamento de Policía Federal del Estado de MS, el Sistema de Control de Bienes Incautados, el Sistema Nacional de Información 
Tóxico-Farmacológica y el Instituto Brasileño de Geografía y Estadística, y por la agencia no oficial de la Unión Nacional de la Industria de Productos para la Protección Fitosanitaria. Los resultados indicaron que en 2011 el estado de MS tuvo el mayor número de incautaciones de pesticidas ilegales en comparación con otros años. Además, de 2010 a 2013, el estado estuvo entre las regiones con el mayor número de incautaciones. En el mismo período, la productividad agrícola de los cultivos de algodón, caña de azúcar, maíz y soja fue menor en comparación con los otros años. Con respecto a la intoxicación alimentaria, el porcentaje de intoxicación humana por agroquímicos para uso agrícola fue bajo en comparación con todos los casos de intoxicación por diversos agentes tóxicos. Se concluyó que el estado MS presentó una gran cantidad de incautación de pesticidas ilegales.

Palabras clave: agroquímicos, intoxicaciones alimentarias, contrabandistas de pesticidas, toxicología de pesticidas, agricultura neotropical.

\section{INTRODUCTION}

The use of agricultural pesticides still is essential to supply the market and ensure the world's food supply, since it's use increases productivity and quality in food production (Passos and Reis, 2013). Starting in 1970, the Green Revolution has promoted the intensive use of agricultural pesticides with the aim of increasing agricultural productivity and solving the hunger problem around the globe. Despite this, other problems have arisen due to the indiscriminate use of these compounds, such as contamination of the environment and hazards to human health (Andrades and Ganimi, 2007).

The pesticides have several types of classification: according to the chemical structure, in relation to neurotoxicity, the effects it causes to human health and the action of its active principle in the target organism (Savoy, 2011). The most common way of classifying pesticides is in relation to the active principle, divided into the following types: insecticides (insect control), herbicides (control of invasive plants), fungicides (elimination of fungi), nematicides (combating nematodes), fumigants (control of bacteria in the soil), acaricides (elimination of mites), molluscicides (mollusc control), as well as growth regulators, desiccants and defoliants (control of interfering leaves). Among these compounds, the insecticides and herbicides are the most used classes (Terra, 2008). Some investigations (Carvalho and Schiesari, 2015) have emphasized the importance of knowing the active principles, taking into account that they are responsible for the toxic action of the compounds and that there are several formulations containing the same active principle but they can vary in concentrations and inert ingredients.

Regarding the situation in Brazil one of the majorglobalplayersin agriculture, to maintain high as productivity levels, it is of agriculture pesticides, highly dependent on, which it is also the largest consumer in the world (Souza et al., 2009). Such huge commercial market had obviously attracted international companies that licitly commercialize such products, but it has also opened the possibilities for the so called pesticide smugglers. The precise amount of illegal products such as active principles or inert substances banned in the country is not so accurate in federal agencies like the Ministry of Agriculture, Cattle and Supplying (Ministério da Agricultura, Pecuária e Abastecimento, MAPA), the Ministry of Health and the Brazilian Institute of Environment and Renewable Natural Resources (Instituto Brasileiro do Meio Ambiente e dos Recursos Naturais Renováveis, IBAMA), as there is not a central management for the apprehension of such illegal compounds.

For the registration of pesticides, Brazilian law requires that they comply with the guidelines and requirements of the federal agencies 
responsible for the health, environment and agriculture sectors (Casa Civil, 1989). Thus, the often usage of such illegal products can be very dangerous and increases the risks to the environment, food safety and human health due to the lack of regulation of this products (Fraga, 2012).

In the Brazilian market, illegal insecticides are marketed with values five to ten times lower than legal products (Dorfman et al., 2014). Some Brazilian states such as Rio Grande do Sul, Paraná, Mato Grosso, Mato Grosso do Sul and Goiás have higher rates of pesticide smuggling because neighbor countries (e.g., Uruguay) do not require the agronomic prescription for the purchase of some pesticides, which facilitate their entry through Brazilian boundaries. The above mentioned Brazilian states have frequent records of illegal pesticide apprehensions (Dorfman et al., 2014). Between the years of 2012 and 2017, the State of Mato Grosso do Sul was among the four states with the highest number of reported illegal pesticides. Lemos et al. (2018) pointed out that, in this period, the active ingredients that were most identified in clandestine products were the insecticides imidacloprid, amamectin benzoate, fipronil and the herbicide metsulfuron-methyl.

In order to provide a better understanding of the commercialization of illegal pesticides in Brazil, we conducted surveys aiming to determine the profile of apprehended pesticides in the state of Mato Grosso do Sul, one of the most relevant agricultural frontiers in Brazil, during the period from 2010 to 2017 as well as the agricultural productivity and human poisoning in this period.

\section{MATERIAL AND METHODS}

Brazilian states with the largest number of illegal pesticide apprehensions. Official information on the number of apprehension for illegal pesticides in Brazil from 2010 to 2017 was provided by the System of Control of Seized Goods (Sistema de Controle de Mercadorias Apreendidas, CTMA). For this, the data request was made through the access to the Electronic System of the Citizen Information Service (Sistema Eletrônico do Serviço de Informação ao Cidadão, e-SIC), of the Ministry of Finance (Ministério da Fazenda).

The data provided by CTMA were grouped by fiscal regions (i.e., Regiões Ficais - RF) that refers to the geographical regions of Brazilian states. For instance, the RF1 comprehend the Brazilian states of Distrito Federal, Goiás, Mato Grosso, Mato Grosso do Sul e Tocantins; RF2 comprehend the Brazilian states of Acre, Amapá, Amazonas, Pará, Roraima e Rondônia; RF3 comprehend the Brazilian states of Ceará, Maranhão e Piauí; RF4 comprehend the Brazilian states of Alagoas, Paraíba, Pernambuco e Rio Grande do Norte; RF5 comprehend the Brazilian states of Bahia e Sergipe; RF6 comprehend the Brazilian states of Minas Gerais; RF7 comprehend the Brazilian states of Espírito Santo e Rio de Janeiro; RF8 comprehend the Brazilian state of São Paulo; RF9 comprehend the Brazilian states of Paraná and Santa Catarina, and RF10 comprehend the Brazilian state of Rio Grande do Sul.

The unofficial data was provided by the National Union of the Product Industry for Plant Protection (Sindicato Nacional da Indústria de Produtos para Defesa Vegetal, SINDIVEG, 2018).

Apprehension of illegal pesticides in the state of Mato Grosso do Sul. The information on the number of apprehension of illegal pesticides in the state of Mato Grosso do Sul 2010 to 2017 was provided by the Scientific Technical Sector of the Regional Superintendence of the Federal Police of Mato 
Grosso do Sul. For this, the data request was made through the access to the website of the Brazilian Federal Police and requesting reports on the profile of pesticides apprehended in the Mato Grosso do Sul state from 2010 to 2017. Data were collected from the reports of the Information System on Criminal Bases (Sistema de Informações em Bases Criminais, SISCRIM). From the data, an identification of the substance, type of pesticide, origin and registration in Brazilian Health Regulatory Agency (Agência Nacional de Vigilância Sanitária, 2003) and MAPA were performed.

\section{Data collection concerning human poisoning} by toxicagent and circumstances. Data related to human intoxication in Brazil from 2010 to 2017 were provided by the Ministry of Health. For this, the data request was made through the access to the website of the National ToxicPharmacological Information System (Sistema Nacional de Informações Tóxico-farmacológicas, SINITOX, 2018), which is the currently agency responsible for the compilation of annual poisonings (independent of the toxic agent origin) in the Brazilian territory.

Agricultural Productivity in the state of Mato Grosso do Sul. Agricultural productivity data were provided by the Brazilian Institute of Geography and Statistics (]Instituto Brasileiro de Geografia e Estatística, 2018). Data were collected from the Municipal Agricultural Production (Produção Agrícola Municipal, PAM) report. The agricultural production and the agricultural yield for the cotton, sugarcane, corn and soybean crops in the state in the state of Mato Grosso do Sul from 2010 to 2017 were evaluated.

\section{RESULTS AND DISCUSSION}

Illegal pesticide apprehension. According to federal agency CTMA, the $R F 9$ was the only fiscal region that was among those that presented the highest number illegal pesticide apprehensions throughout the period analyzed. In addition to this region, others can be identified (Table 1).

Table 1. Fiscal regions in seizures of illegal agrochemicals.

\begin{tabular}{ccccc}
\hline Year & Fiscal Regions & Corresponding States & $\begin{array}{c}\text { Apprehension } \\
\text { (\%) }\end{array}$ & $\begin{array}{c}\text { Other Regions } \\
\text { (\%) }\end{array}$ \\
\hline 2010 & $R F 1 ; R F 9 ; R F 10$ & DF; GO; MT; MS; TO; PR; SC; RS & $99.7 \%$ & $0.3 \%$ \\
2011 & $R F 1 ; R F 9 ; R F 10$ & DF; GO; MT; MS; TO; PR; SC; RS & $56 \%$ & $44 \%$ \\
2012 & $R F 1 ; R F 9 ; R F 10$ & DF; GO; MT; MS; TO; PR; SC; RS & $99 \%$ & $1 \%$ \\
2013 & $R F 1 ; R F 9 ; R F 10$ & DF; GO; MT; MS; TO; PR; SC; RS & $98 \%$ & $2 \%$ \\
2014 & $R F 8 ; R F 9 ; R F 10$ & SP; PR; SC; RS & $96 \%$ & $4 \%$ \\
2015 & $R F 8 ; R F 9 ; R F 10$ & SP; PR; SC; RS & $89 \%$ & $11 \%$ \\
2016 & $R F 8 ; R F 9 ; R F 10$ & SP; PR; SC; RS & $97 \%$ & $3 \%$ \\
2017 & $R F 6 ; R F 9 ; R F 10$ & MG; PR; SC; RS & $93 \%$ & $7 \%$ \\
\hline
\end{tabular}

Source: CTMA, 2018. DF = Distrito Federal; GO = Goiás; MT = Mato Grosso; MS = Mato Grosso do Sul; TO = Tocantins; PR = Paraná; SC = Santa Catarina; RS = Rio Grande do Sul; SP = São Paulo; MG = Minas Gerais 
Apprehension of illegal pesticides in Mato Grosso do Sul. Data on illegal pesticide apprehension in Mato Grosso do Sul, according to non-official agency SINDIVEG are presented in the Figure 1.

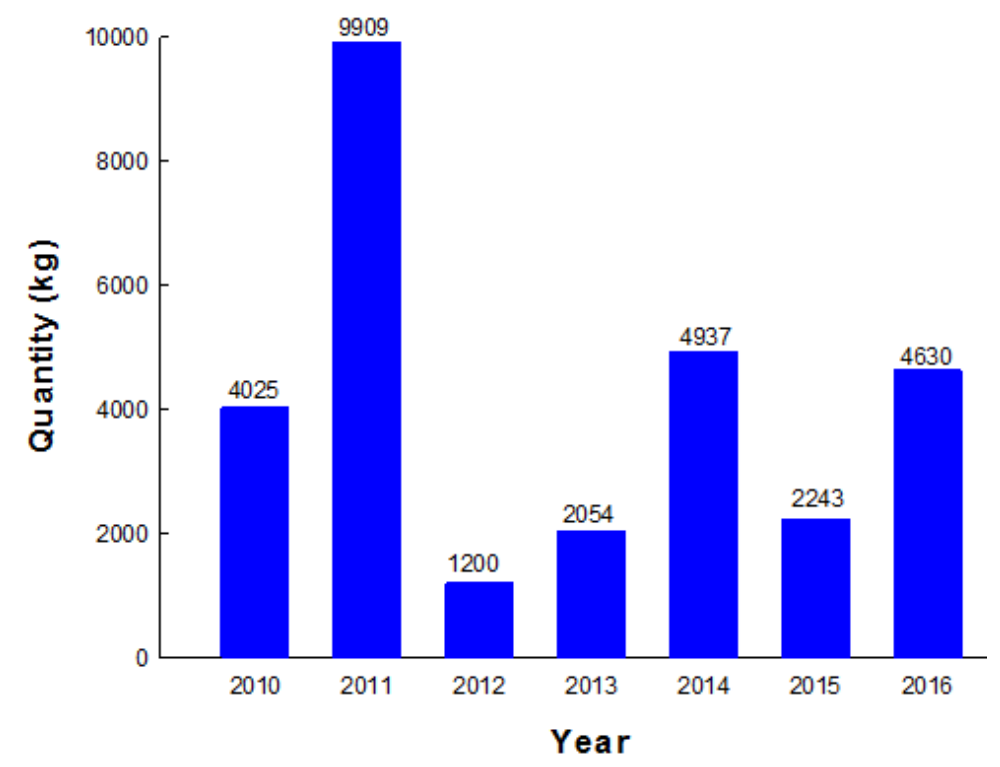

Figure 1. Apprehension of illegal agricultural pesticides in the state of Mato Grosso do Sul (SINDIVEG, 2018).

According to the federal agency SISCRIM, the Federal Police of Mato Grosso do Sul reported, between 2010 and 2017, the apprehension of 80 products in allegedly illegal situations. Figure 2 shows the annual distribution of reports.

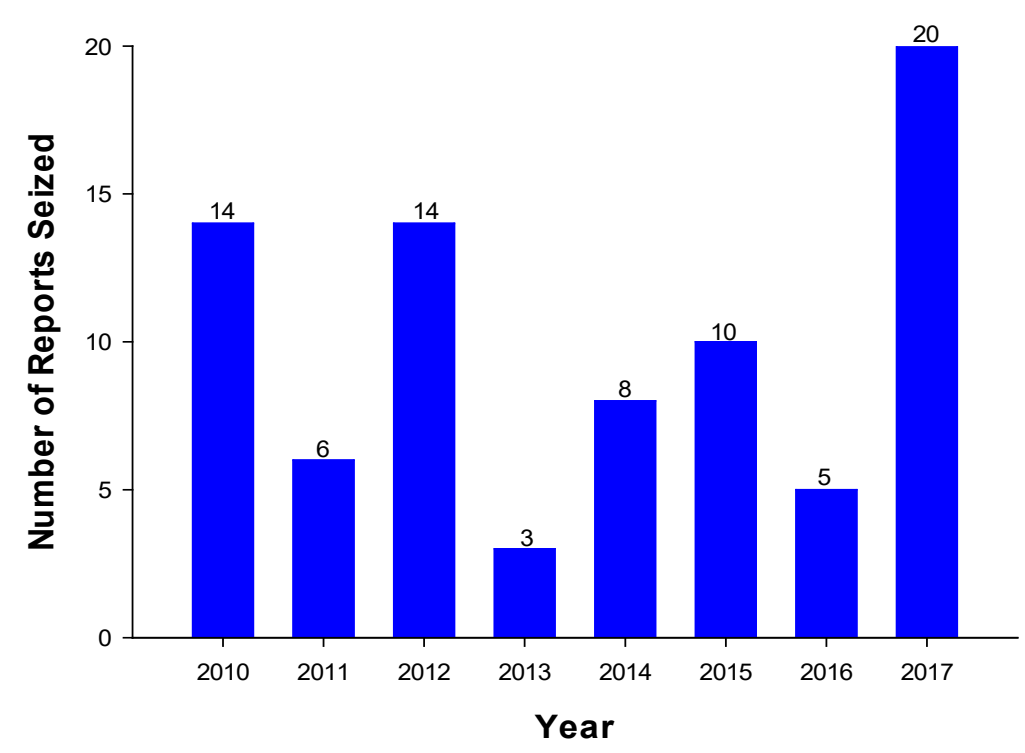

Figure 2. Annual distribution of reports in the state of Mato Grosso do Sul (SISCRIM, 2018). 
The most frequent active principles apprehended in the state of Mato Grosso do characterized among the illegal products Sul, from 2010 to 2017 are shown in Table 2.

Table 2. Most frequent active principles detected in apprehended illegal products.

\begin{tabular}{|c|c|c|c|}
\hline \multicolumn{4}{|c|}{ Active Principles per Year } \\
\hline 2010 & 2011 & 2012 & 2013 \\
\hline $\begin{array}{l}\text { Chlorimuron Ethyl } \\
\text { Imidacloprid } \\
\text { Acetamiprid } \\
\text { Fipronil }\end{array}$ & $\begin{array}{l}\text { Acetamiprid } \\
\text { Carbofuran }\end{array}$ & $\begin{array}{l}\text { Acetamiprid } \\
\text { Imidacloprid } \\
\text { Fipronil }\end{array}$ & $\begin{array}{l}\text { Methylsulfuromethyl } \\
\text { Fipronil }\end{array}$ \\
\hline 2014 & 2015 & 2016 & 2017 \\
\hline $\begin{array}{l}\text { Acetamiprid } \\
\text { Imidacloprid } \\
\text { Methylsulfuromethyl }\end{array}$ & $\begin{array}{l}\text { Acetamiprid } \\
\text { Thiamethoxan } \\
\text { Methylsulfuromethyl }\end{array}$ & Thiamethoxan & $\begin{array}{l}\text { Acetamiprid } \\
\text { Emamectin Benzoate } \\
\text { Imidacloprid } \\
\text { Thiamethoxan }\end{array}$ \\
\hline
\end{tabular}

\section{Human poisoning in Brazil}

The SINITOX presented information on 19 types of toxic agents. Table 3 identifies some of these agents that contributed the most to human intoxication rates between 2010 and 2017.

Table 3. Registered cases of human intoxication by toxic agent (Sinitox, 2018).

\begin{tabular}{lrrrrrrrr}
\hline \multirow{1}{*}{ Agents } & \multicolumn{7}{c}{ Cases Recorded per Year (\%) } \\
\cline { 2 - 9 } & $\mathbf{2 0 1 0}$ & $\mathbf{2 0 1 1}$ & $\mathbf{2 0 1 2}$ & $\mathbf{2 0 1 3}$ & $\mathbf{2 0 1 4}$ & $\mathbf{2 0 1 5}$ & $\mathbf{2 0 1 6}$ & $\mathbf{2 0 1 7}$ \\
\hline Medicament & 26.81 & 28.51 & 27.32 & 28.04 & 29.82 & 31.55 & 34.04 & 25.18 \\
Household Cleaning Products & 10.82 & 10.60 & 7.94 & 8.26 & 11.50 & 9.97 & 9.62 & 5.04 \\
Scorpions & 10.68 & 10.09 & 11.52 & 10.66 & 10.97 & 11.55 & 13.95 & 36.04 \\
Other Animals Venomous & 5.62 & 5.10 & 4.60 & 4.91 & 4.23 & 6.78 & 1.82 & 2.55 \\
Drugs of Abuse & 6.54 & 6.17 & 7.64 & 6.62 & 3.76 & 4.01 & 3.58 & 2.54 \\
Agrochemicals for Agricultural Use & 5.35 & 4.78 & 4.63 & 4.46 & 3.78 & 3.66 & 3.57 & 3.97 \\
Industrial Chemicals & 5.33 & 5.75 & 5.06 & 5.94 & 4.96 & 4.39 & 4.69 & 2.65 \\
Others & 28.85 & 29.00 & 31.29 & 31.11 & 30.98 & 28.09 & 28.73 & 22.03 \\
\hline
\end{tabular}


Agricultural production and productivity in the state of Mato Grosso do Sul. The agricultural products of the state of Mato Grosso do Sul that were part of the Municipal Agricultural Production (Produção Agrícola Municipal, PAM) report issued by IBGE (2018) were: Pineapple (Ananas comosus), cotton (Gossypium hirsutum), peanuts (Arachis hypogaea), rice (Oryza sativa), oats (Avena sativa), sugarcane (Saccharum officinarum), beans (Phaseolus vulgaris), sunflower (Helianthus annuus), cassava (Manihot esculenta), watermelon (Citrullus lanatus), soybeans (Glycine max), sorghum (Sorghum bicolor), tomatoes (Solanum lycopersicum), wheat (Triticum aestivum) and corn (Zea mays). The Figure 3 shows the agricultural production for the cotton, sugarcane, corn and soybean crops in the state during the period evaluated.

The agricultural yields for the cotton, sugar cane, corn and soybean crops in the state of Mato Grosso do Sul and in Brazil are highlighted in Figures 4.

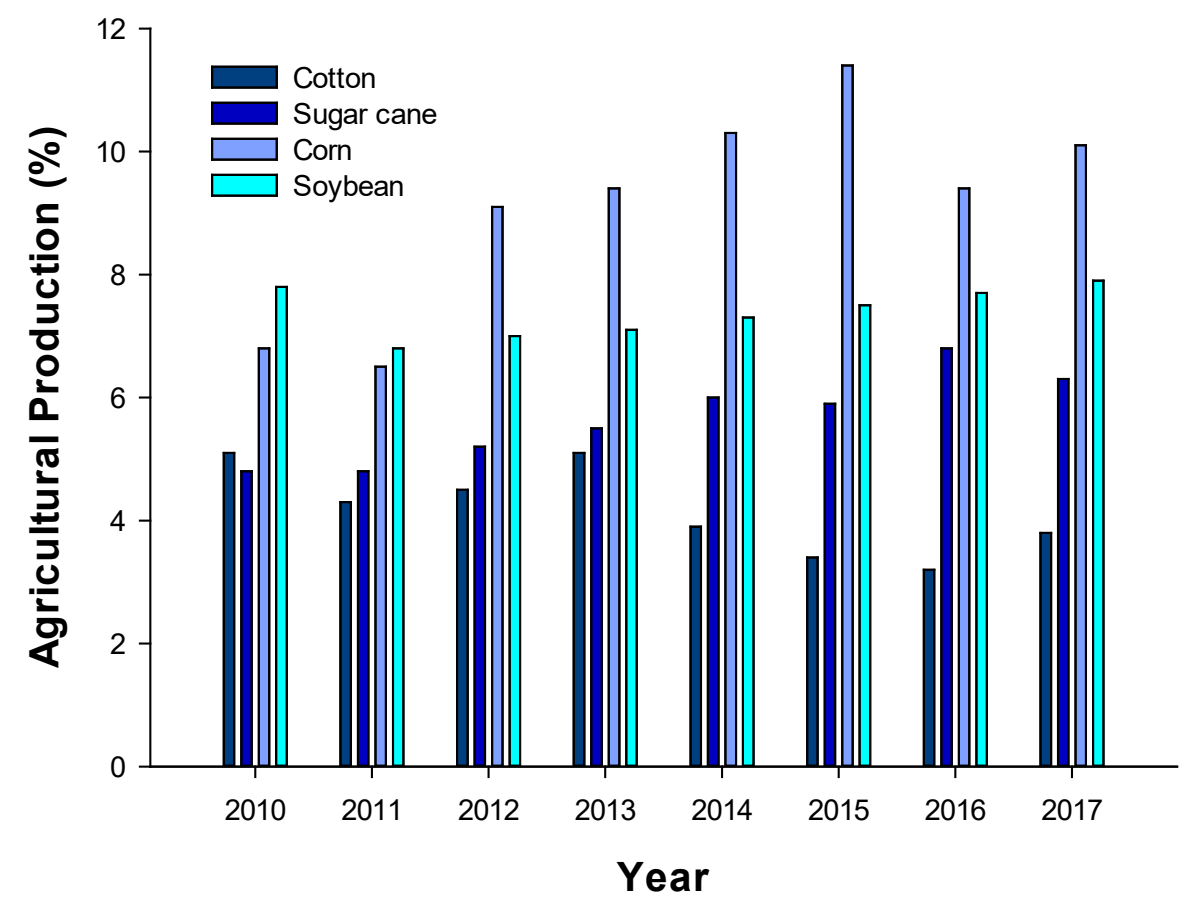

Figure 3. Agricultural production in the state of Mato Grosso do Sul. Data show the percentage of production in relation to the national production in the respective years. 

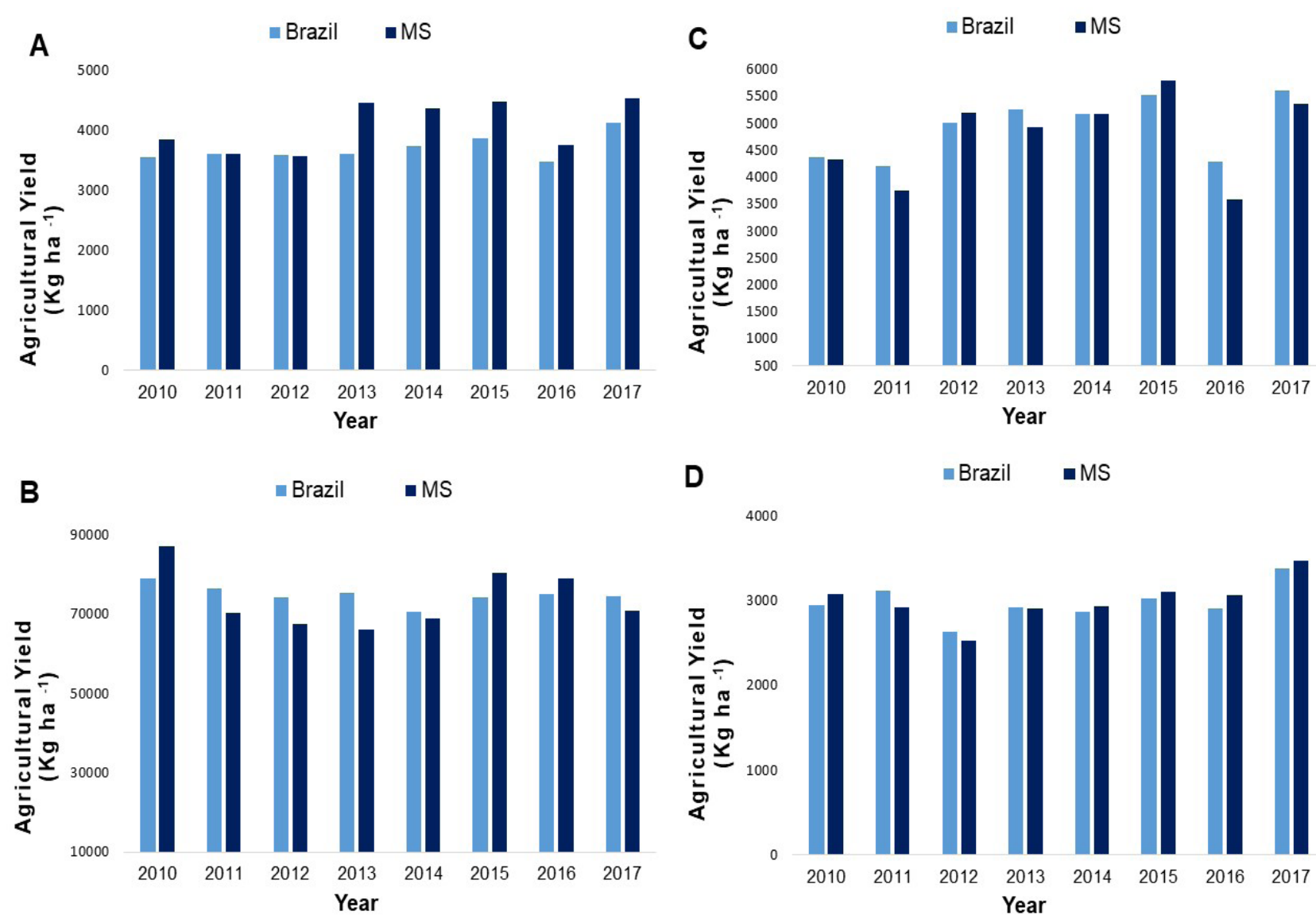

Figure 4. Average yield of national production and in the state of Mato Grosso do Sul for cotton (A), sugar cane (B), corn (C) and soybean (D) (IBGE, 2018 - Municipal Agricultural Production).

The $R F 1, R F 9$ and $R F 10$ fical regions presented the highest number illegal pesticide apprehensions between the years of 2010 and 2013 (Table 1). Such regions comprise a large number of Brazilian states, including the state of Mato Grosso do Sul. The Mato Grosso do Sul state presented a high number of illegal pesticide apprehensions, especially in the year of 2011 (Figure 1). Although the SINDIVEG (2018) is not an official agency, it can provide relevant data, as they made possible to classify the apprehension results by Brazilian state. Furthermore, the data on annual reports in the State of Mato Grosso do Sul do not reflect the total amount of illegal pesticides seized (Figure 2). Thus, the data provided by the official agencies (i.e., Ministry of Finance) could not clearly describe the actual picture of seizures in a territory of single Brazilian state.

This position obtained by the Mato Grosso do Sul state in the rankings can be explained by the fact that this region is an agricultural and boundary frontier, which facilitates the entry of these illegal products by this region. Similar situation can be perceived in other agricultural and boundary frontier states (e.g., Paraná and Rio Grande do Sul), which is the most common pathway used to bring these illegal products to other states (e.g., São Paulo) where agriculture is also very relevant. 
The most prevalent agronomic category in the apprehended pesticides was the synthetic insecticides, according to the most frequent active principles detected (Table 2). We can highlight the neonicotinoid insecticides imidacloprid, acetamiprid and thiamethoxam but also the fenylpyrazoles fipronil. Such assumption makes even more sense if we consider that these active principles are among the most used in the agricultural crops planted in the Mato Grosso do Sul state. Although these active principles being commonly found in legally products marketed in Brazil, the apprehended products were not authorized at that time by MAPA agency, which turn their importation, commercialization and use in Brazil as illegal actions.

Regarding the occurrence of human intoxication (Table 3), from the data analyzed from 2013 up to now, we can a false idea that there was a reduction in the number of intoxication by agrochemicals for agricultural use. In fact, the smaller numbers result from the low participation of the Information Centers and Toxicological Assistance (Centros de informação e Assistência Toxicológicas, CIATS) for registering such data (Azevedo, 2006). CIATS act to assist the intoxicated patient and provide information and guidance on diagnosis, prognosis, treatment and prevention of poisoning. Based on available data, intoxications were primarily caused by medications (i.e., pharmaceuticals). In relation to pesticides for agricultural use, there are few intoxication records and intoxication by food intake was less than $0.5 \%$ of the records. Despite data available for illegal pesticide seizures and occurrence of human intoxication, it is not possible to establish a correlation between such parameters, as statistical data are lacking to establish such correlations.
Interestingly, it can be said that the Brazilian Central-Midwestern regions, where the state of Mato Grosso do Sul is located, has more expressive records of food poisoning. Of the total national registries, approximately 54\% of total of records in the entire country (for the years of 2010 to 2013) were reported in these region. When we took an extended period (i.e., from the year 2010 up to the year of 2016), there were 52 records of food poisoning in Brazil, which surely is an amount that is far distant of the reality. These records were certainly related only for the acute or immediate intoxication, not taking in consideration the potential intoxication derived of chronic (i.e., for longer time periods) exposures.

It is difficult to establish the relationship between food contamination and illegal pesticide apprehension, since the data provided by non-official agency SINITOX brings data referring only to the number of intoxications and does not bring data regarding the food type that potentially caused the intoxication. Recent investigation (Carneiro et al., 2015) have emphasized the need of studying the presence of pesticide residues in the diversity of food consumed by humans. The lack of data regarding this also turn such the potential correlation between human intoxication and the use of illegal pesticides an even more complex task.

As discussed above, from 2010 to 2013, Mato Grosso do Sul state was among the regions with the largest number of illegal pesticide apprehensions, according to CTMA and SINDVEG (2018) data (Table 1 and Figure 1). Within this period, it was possible to observe a lower agricultural productivity of the evaluated crops compared to the rest of the period analyzed, according to PAM report 
(Figure 3). In 2011, when it occupied the second place in seizures, about $71 \%$ of the crops presented yields below the national average. In 2012 it presented similar income to the previous year, which may be a reflection of the previous harvest. In 2013, when the fiscal region to which the state belongs ranked first in seizures, 59\% of the crops presented agricultural yields lower than the national average. In 2015 , about $71 \%$ of crops presented yields below the national average and the state ranked third in the number of pesticides apprehended. On the other hand, in the years 2016 and 2017, more than half of their crops showed yields above the national productivity average, and it was also verified that both official and unofficial data pointed to a reduction in apprehension of illegal products. It is possible to infer a relation in the reduction of the apprehension, which may be due to the reduction of the entry of illegal products in the state, thus contributing to an increase in crop productivity. Fraga (2012) corroborates with the understanding that the use of illegal products interfered with their effectiveness to keep the higher agricultural productions, which may be due to the low reliability of the chemical composition.

\section{CONCLUSIONS}

From 2010 to 2013, the state of Mato Grosso do Sul was among the regions in Brazil that had the largest number of seizures of illegal pesticides. Additionally, during this period, the agricultural productivity of cotton, sugarcane, corn and soybean crops was lower than in the other years of analysis.

Cases of human intoxication by agrochemicals for agricultural use corresponded to a small percentage compared to cases of human intoxication by various toxic agents in Brazil during the period evaluated.
Despite all the reports from the official and non-official agencies operating in the country, there is a lack of data that correlates the number of seizures of illegal pesticides with data on agricultural productivity and human intoxication by agrochemicals. A detailed analysis of such correlations in each Brazilian state will allow a greater understanding of the impacts of the commercialization of illegal pesticides on agriculture and the health of the population.

Conflict of interest: The authors declare that there is no conflict of interest.

\section{BIBLIOGRAPHIC REFERENCES}

Agência Nacional de Vigilância Sanitária. (2017). Relação de Monografias dos Ingredientes Ativos de Agrotóxicos, Domissanitários e Preservantes de Madeira, Benzoato de Emamectina. Retrieved from http://portal. anvisa.gov.br/registros-e-autorizacoes/ agrotoxicos/produtos/monografia-deagrotoxicos/autorizadas.

ANVISA- Agência Nacional de Vigilância Sanitária. (2003). Consulta Pública № 50, de 09 de junho de 2003. Regularização de Produtos Agrotóxicos, Ministério da Sáude, Diário Oficial da União. Brasil. Recovered from http://portal. anvisa.gov.br/agrotoxicos

Andrades, T.O. \& Ganimi, R.N. (2007). Revolução verde e a apropriação capitalista. CES Revista. 21:43-56.

Azevedo, J.L.S. (2006). A Importância dos Centros de Informação e Assistência Toxicológica e sua Contribuição na Minimização dos Agravos à Saúde e ao Meio Ambiente no Brasil. Retrieved from http://repositorio.unb.br/ handle/10482/4740 
Casa Civil. (1989). Lei № 7.802, de 11 de julho de 1989, emitida pela Presidência da República do Brasil. Retrieved from http://www.planalto. gov.br/ccivil_03/LEIS/L7802.htm

Carneiro, F., Rigotto, R., Augusto, L., Friedrich, K., Búrigo, A. (2015). Dossiê ABRASCO: um alerta sobre os impactos dos agrotóxicos na saúde. São Paulo: Expressão Popular. 624p.

Schiesari, L. (2012) Defensivos agrícolas: como evitar danos à saúde e ao meio ambiente. Instituto de Pesquisa Ambiental da Amazônia, Série Boas Práticas. Retrieved from https:// ipam.org.br/wp-content/uploads/2012/08/ defensivos_agrícolas_como_evitar_danos_à.pdf

Dorfman, A., França, A. \& Soares, G. (2014). Marcos legais e redes de contrabando de agrotóxicos: análise escalar a partir da fronteira BrasilUruguai. Terra Plural. 8(1): 37-53. doi: 10.5212/TerraPlural.v.8i1.0002

Fraga, W.G. (2012). Identificação e determinação dos principais ingredientes ativos em agrotóxicos ilegais apreendidos pela polícia federal do Brasil. Retrieved from http:// repositorio.unb.br/handle/10482/11569

IBGE - Instituto Brasileiro de Geografia e Estatística. (2018). Área plantada, área colhida, quantidade produzida, rendimento médio e valor da produção das lavouras temporárias. Produção Agrícola municipal, Mato Grosso do Sul, Brasil. Retrieved from https://sidra.ibge. gov.br/tabela/1612

Lemos, V.F., Carvalho, A.C.B. \& Ortiz, R.S. (2018). Perfil nacional de apreensões de agrotóxicos pela Polícia Federal. Revista Brasileira de Criminalística. 7(1):21-25.

Passos, F. R., \& Dos Reis, M. R. (2013). Resíduos de agrotóxicos em alimentos de origem vegetal: revisão. Pesticidas: Revista de Ecotoxicologia e Meio Ambiente. 23: 49-58. doi: http://dx.doi. org/10.5380/pes.v23i0.35002

Savoy, V. L. T. (2011). Classificação dos agrotóxicos. Biológico. 73(1):91-92.
SINDIVEG - Sindicato Nacional da Indústria de Produtos para Defesa Vegetal. (2018). Estatísticas do setor. Retrieved from http:// sindiveg.org.br/defensivos-ilegais/

SINITOX-Sistema Nacional de Informações TóxicoFarmacológicas. (2018). Dados de intoxicação. Retrieved from https://sinitox.icict.fiocruz. br/dados-nacionais.

SISCRIM - Sistema de Informações em Bases Criminais. (2018). Relatório - Laudo de exame de agrotóxico - 2010-2017. Retrieved from http://www.pf.gov.br/institucional/ unidades/superintendencias-e-delegacias / mato-grosso-do-sul.

Souza, D. Z., Rossato, L.G., Limberger, R.P. \& Dallegrave, E. (2009). Agrotóxico no Rio Grande do Sul: o grave problema do contrabando. Toxicovigilância - Toxicologia Clínica: dados e indicadores selecionados Rio Grande do Sul 2008-2009. Brasil: Centro de Informação Toxicológica do Rio Grande do Sul (CIT) da Secretaria Estadual de Saúde.

Terra, F.H.B. (2008). A indústria de agrotóxicos no Brasil. Retrieved from https://acervodigital. ufpr.br/handle/1884/15861 